\title{
Geological and tectonic preconditions for hydraulic heterogeneity of the rocks in the area of the Gotse Delchev valley
}

\author{
Peter Gerginov ${ }^{l}$
}

${ }^{1}$ Geological Institute, Bulgarian Academy of Sciences, 1113, Sofia, Bulgaria;

e-mail: p.gerginov@mail.bg

\section{Геолого-тектонски предпоставки за филтрационната нееднородност на скалите в района на Гоце-Делчевската котловина}

\author{
Петьр Гергинов
}

Gerginov, P. 2021. Geological and tectonic preconditions for hydraulic heterogeneity of the rocks in the area of the Gotse Delchev valley. Engineering Geology and Hydrogeology, 35, 51-61.

\begin{abstract}
Hydrogeological conditions largely depend on the permeability of the geological environment. In areas with complex geological and tectonic conditions, the detection of hydraulic heterogeneity of the rocks and determination of groundwater-rich zones is a challenge for hydrogeological practice. The aim of the study is to analyze the geological and tectonic prerequisites for hydraulic heterogeneity of the sediments for the Gotse Delchev valley (Southwestern Bulgaria), which predetermine the degree of their water productivity. In order to obtain more precise data for specific sites, a geophysical survey was conducted. The Self-Potential method was chosen, which is one of the most commonly used techniques for applications for hydrogeological purposes. The results of the geophysical survey carried out in selected sites allowed to locate groundwater-rich zones, to establish the depth of occurrence of hard low permeable rocks, as well as to confirm the presence of faults.
\end{abstract}

Keywords: groundwater productivity, geophysical survey, SP method, Bulgaria.

Резюме. Хидрогеоложките условия в значителна степен зависят от пропускливостта на геоложката среда. В райони със сложни геолого-тектонски условия изясняването на филтрационната нееднородност на скалите и очертаването на оводнени зони е предизвикателство за хидрогеоложката практика. Целта на изследването е да се анализират геолого-тектонските предпоставки за филтрационната нееднородност на отложенията в района на Гоце-Делчевската котловина (Югозападна България), които предопределят степента на тяхната водоносност. За по-прецизна характеристика на свойствата на скалите в няколко характерни участъка е приложено геофизично проучване с цел да се локализират по-водообилните зони. Използван е методът на собствения потенциал, което е практика при хидрогеоложките изследвания. Резултатите от геофизичното проучване, проведено в избрани участъци, позволиха да се локализират водообилни зони и преференциални пътища на потока на подземните води, да се установи дълбочината на залягане на по-плътни скали, както и да се потвърди наличието на разломни нарушения.

Ключови думи: подземни води, водообилни зони, геофизично проучване, SP метод, България 


\section{Introduction}

Detecting heterogeneity of porous media is an important stage in the schematization of hydrogeological conditions and the development of conceptual models. The geological and tectonic development of this territory largely determines the composition and properties of rocks; therefore, their analysis is important for the characterization of aquifers. The permeability of the rocks largely depends on the lithological composition of the rocks, the degree of their weathering, as well as on the tectonic processing of the rocks. It is known that faults, as well as the contact zones between different rocks, depending on their permeability, can provide preferential pathways for groundwater, or vice versa, represent a practically impermeable screen for water.

The object of the present study is the Gotse Delchev valley located in the middle reaches of the Mesta river. In order to establish the regional hydrogeological characteristics, the geological-lithological composition and the tectonic structure of the Gotse Delchev valley are analyzed. The Neotectonic development of this region is marked by extension leading to the formation of a graben structure with an impact on the relief features. The aim of the study is to analyze the geological and tectonic prerequisites for the hydraulic heterogeneity of the rocks in the study area. In addition, a geophysical study was conducted in several selected sites to discover the local geological structures and localization of the groundwater-rich zones.

In general, geophysical surveys have good potential to detect specific geological and hydrogeological features. Mitev and Yaneva (2013) demonstrated application of $2 \mathrm{D}$ resistivity profiling to recognize and determine the sediment successions in areas with lack of outcrops in six sites located in the Gotse Delchev valley. Hydrogeophysics as a research field emerged in the late 1990s, and since then there has been an increase in hydrogeophysical articles (Binley et al., 2015). Although they do not provide direct information on rock properties, geophysical measurements have been successfully applied in hydrogeological practice to solve a number of problems (Kirsch, 2006).

\section{Territorial scope, geological structure and tectonic setting}

The Gotse Delchev valley with a total area of $122 \mathrm{~km}^{2}$ is located in the middle reaches of the Mesta river and is bounded on the west by the Pirin Mountains and on the east by the Western Rhodopes (Fig. 1). The relief of the valley is predominantly flat, sloping towards the valley of the Mesta river. It is separated from the Razlog valley to the north by Momina Gorge of the Mesta river. The northwestern part of the valley is mostly hilly.

The valley is filled with Paleogene, Neogene and Quaternary sediments. PreCambrian sediments are found on its periphery. The deposits are described in Explanatory Notes to the Geological Map of Bulgaria in scales of 1:100000 and 1:50000 for the respective map sheets (Kozhoukharov, Marinova, 1994; Klimov, Sarov, 2009; Sarov, 2010).

PreCambrian, Paleogene, Neogene and Quaternary rocks are developed in the study area.

\section{PreCambrian}

The PreCambrian sediments are referred to the Rhodope Supergroup composed of three groups: Rupchoska, Sitovo and Asenovgrad (Kozhoukharov, Marinova, 1994). Their outcrops are on the periphery of the Gotse Delchev valley.

The Rupchoska Group includes three Formations: Chepelare, Bogutevo and Vacha. The Chepelare Formation is composed of biotite and double mica gneisses, gneiss schists, shales, marbles, amphibolites. The Bogutevo Formation consists of plagiogneisses in many places intensively migmatised. The Vacha Variegated Formation is represented by amphibole-biotite, biotite and double mica gneisses, marbles, and amphibolites. 


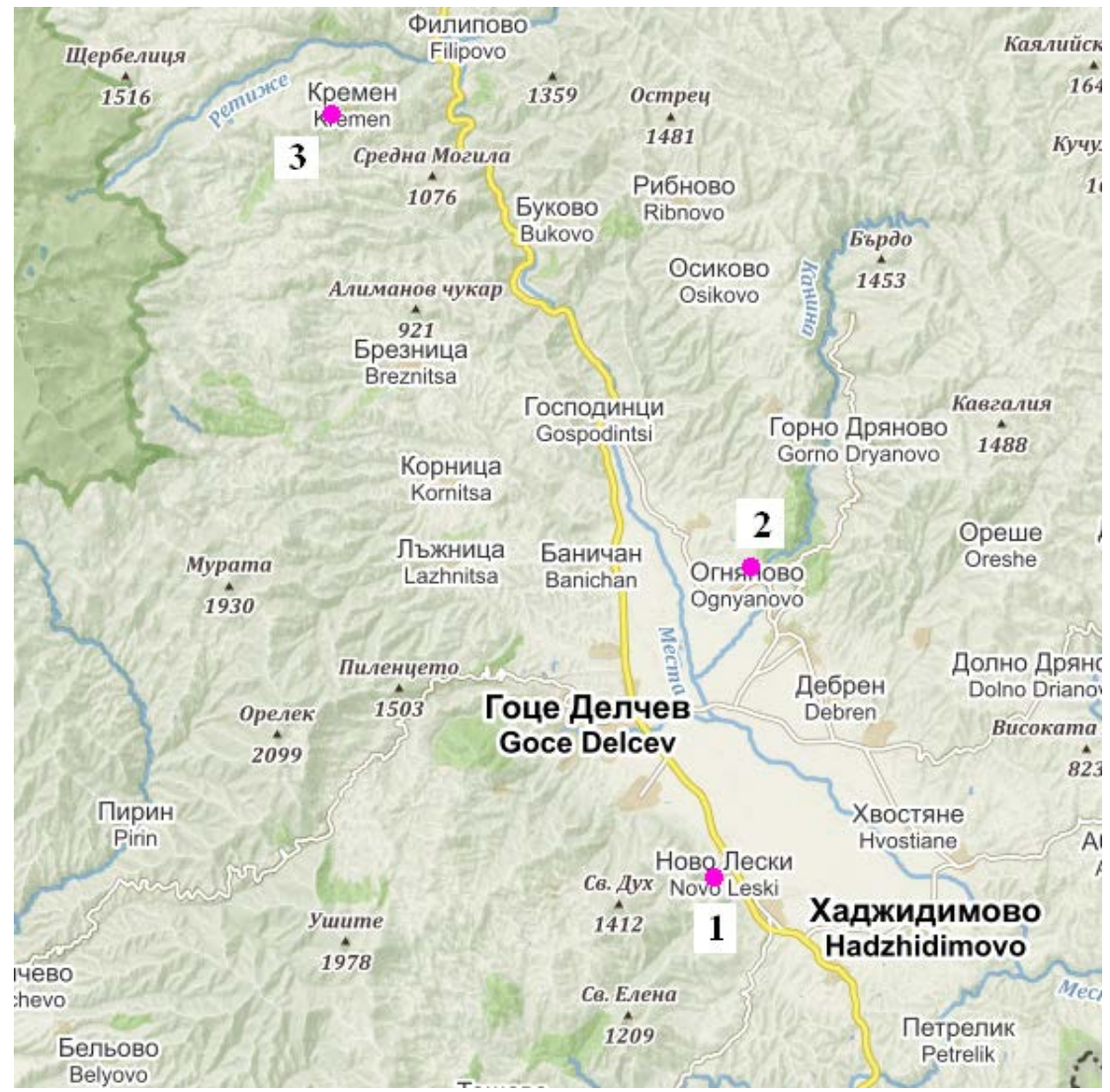

Fig. 1. Location of sites for geophysical profiling in the Gotse Delchev valley (1-Novo Leski village, 2-Ognianovo village, 3-Kremen village)

Фиг. 1. Местоположение на участьците на геофизично профилиране в Гоце-Делчевската котловина (1 с.Ново Лески, 2 - с.Огняново, 3 - с.Кремен)

The Rupchoska Group includes three Formations: Chepelare, Bogutevo and Vacha. The Chepelare Formation is composed of biotite and double mica gneisses, gneiss schists, shales, marbles, amphibolites. The Bogutevo Formation consists of plagiogneisses in many places intensively migmatised. The Vacha Variegated Formation is represented by amphibole-biotite, biotite and double mica gneisses, marbles, and amphibolites.

The Sitovo Group consists of three Formations as follows: Lukovo gneiss-schist Formation, Bachkovo leptinite Formation, Boikovo gneiss Formation.

The Asenovgrad Group includes the Dobrostan marble Formation (made of massive and layered marbles).

\section{Paleogene}

The Paleogene in the Mesta Graben is represented by sedimentary, volcanicsedimentary and volcanic rocks. The rapid lateral and vertical facies change, as well as the spatial variability of different types of rocks are registered. The lithostratigraphic units recognized in the area are: the Breccia-conglomerate Formation up to $400 \mathrm{~m}$ thick and Volcanic-sedimentary complex (composed of tuffs, tuff breccias, tuff sandstones and conglomerates, etc.). Various subvolcanic bodies and dykes have also been identified (Klimov, Sarov, 2009). 


\section{Neogene}

Neogene sediments are of alluvial-lacustrine origin. They fill the southern parts of the Mesta Graben. The official lithostratigraphic units are: Valevitsa, Baldevo and Nevrokop formations (Kozhoukharov, Marinova, 1994). The Valevitsa Formation is composed of coarse terrigenous rocks: conglomerates and poorly sorted sandstones up to $100-200 \mathrm{~m}$ thick.

The Baldevo Formation consists of sandstones, siltstones, clays, and coal. By genesis, these are mainly lacustrine formations up to 100-250 m thick.

The Nevrokop Formation is widespread in the western part of the basin. It is represented by sands, sandstones and conglomerates up to 500-600 m thick.

\section{Quaternary}

Alluvial deposits outcrop along the Mesta river and its tributaries and are widespread. They are composed of gravel, boulders and poorly sorted sands (up to 40-50 m thick), which overlay the Neogene sediments in the valley of the Mesta River.

Proluvial sediments (gravels, sands) form alluvial-proluvial fans at the periphery of the valley. Only locally they are thicker than $20 \mathrm{~m}$.

\section{Tectonics}

The Gotse Delchev valley occupies the southernmost part of the Mesta Depression. It is a Late Alpine asymmetric structure (one-sided graben), whose formation and development is associated with the manifestation of the Mesta and East Pirin fault zones. This is a stepped depression formed during two stages of extension. During the late Eocene-Oligocene stage the volcanic-sedimentary and volcanic rocks are formed, and during the second (Late Oligocene-Pliocene) the imposed Gotse Delchev graben is formed (Klimov, Sarov, 2009). Its Paleogene filling is of volcanic-sedimentary rocks. The Gotse Delchev graben is filled with Neogene terrigenous sediments, covering rocks of the metamorphic complex and Paleogene sediments and volcanic rocks.

\section{Hydrogeological characteristics}

The porous groundwater in the Gotse Delchev valley is accumulated in the Neogene and Quaternary deposits. Their permeability varies depending on the presence of the clay component in the sediments. The most permeable and water-abundant are the alluvial deposits of the Mesta River and its left tributary, the Kanina River. The alluvium is exposed over $84 \mathrm{~km}^{2}$. The alluvial deposits are $40-50 \mathrm{~m}$ thick, represented by gravels and sands, among which there are clay lenses. The alluvial aquifer is unconfined, it is hydraulically connected to the rivers and drained by the Mesta River (Antonov, Danchev, 1980).

The aquifer formed in the Neogene alluvial-lacustrine sediments of the Gotse Delchev valley is moderately productive. It is unconfined with a confined part. The sand and gravel layers are clayey and therefore low permeable. Thus, despite good protection against pollution, this aquifer has limited groundwater potential.

The karst aquifer is formed in PreCambrian marbles from the Dobrostan Formation (Asenovgrad Group) located in the western periphery of the valley. The marbles are fractured and karstified. Groundwater emerges on the surface as springs in fault zones, generally in contact zones of marbles with the Neogene sediments or PreCambrian metamorphites.

Fractured groundwater is related to the weathering zone of the silicate metamorphites that outcrop in the peripheral parts of the basin. The respective aquifer has a regional distribution and is drained by low flow springs. The springs associated with areas of local tectonic fissures or fracture zones have a higher flow rate.

The settlements in the area of the Gotse Delchev valley are supplied with water from spring waters, from river catchments of alpine type, as well as from pumping stations built in the terrace of the Mesta river. 
Within the boundaries of the Gotse Delchev valley, the alluvial deposits of the Mesta river are with the best water productivity. The hydraulic conductivity values up to $100 \mathrm{~m} / \mathrm{d}$ (with an average value of $45 \mathrm{~m} / \mathrm{d}$ ) were determined in the northern part of the basin, and up to $140 \mathrm{~m} / \mathrm{d}$ in the southern part (Antonov, Danchev, 1980). Proluvial deposits, like Neogene sediments, are less permeable. In any case, local features such as clay content and degree of fracturing are crucial for the productivity of the respective aquifers.

Groundwater formed in different basins is characterized by different chemical composition. Studies of heavy metal pollution in the Mesta River valley were done by defining of Heavy Metal Pollution Index (HPI), and the Metal Index (MI) (Vasileva, Toteva, 2019; Vasileva, 2020; Vasileva, Sholev, 2021).

\section{Research methodology \\ Self-Potential method}

The Self-Potential (SP) method is one of the most commonly used geophysical methods for hydrogeological applications. Like other electrical methods, it allows considerable flexibility in the choice of scale (depth) for research (Binley et al., 2015).

The measurements of SP belong to the early methods used in applied geophysics, and in recent years there has been a growing interest in the application of the SP method in hydrogeology (Kirsch, 2006). This method is based on the measurement of natural electric currents originating from various electrochemical, electrophysical and bioelectrical processes in the geological section. When the electrokinetic effect dominates, SP anomalies can indicate preferential pathways for groundwater flow, identify hydraulically active faults, locate sinkholes and karst cavities, and contact surfaces (Robert et al., 2011).

The SP method is a passive method that is both non-invasive and inexpensive. Its main application in hydrogeology is the delineation of groundwater flow. The resulting geophysical image can be considered as a "proxy" for the spatial distribution of a particular property (e.g. permeability) or mapping of preferential flow paths. A number of successful applications of the SP method are known both abroad and in Bulgaria (for example, Robert et al., 2011; Gerginov, Orehova, 2020). A PQWT S500 equipment was used for geophysical research in the Gotse Delchev valley. The obtained profiles for natural electric potential are generated directly from the equipment used without corrections by the authors.

The equipment manufacturer does not claim that the results obtained are related to quantitative assessments of the degree of water productivity, so they represent mainly a qualitative analysis of hydrogeological conditions.

\section{Sites in the Gotse-Delchev valley for the geophysical survey}

For the geophysical study, three locations for the profiles were selected - near the villages of Novo Leski, Ognyanovo and Kremen (Fig. 1, Table 1). These locations encompass the distribution of granular, fractured and karst aquifers with varying water

Table 1. Geographical coordinates of the profiles and their altitude

Таблица 1. Географски координати на профилите и надморска височина

\begin{tabular}{l|c|c|c}
\hline \multirow{2}{*}{ Profile } & \multicolumn{2}{|c|}{ Geographical coordinates } & \multirow{2}{*}{$\begin{array}{c}\text { Altitude } \\
\text { (m asl) }\end{array}$} \\
\cline { 2 - 3 } & Latitude & Longitude & 560 \\
\hline 1 - Novo Leski & 41.530488 & 23.774642 & 580 \\
- Ognyanovo & 41.616540 & 23.788794 & 1140 \\
3- Kremen & 41.742326 & 23.632530 & \\
\hline
\end{tabular}


productivity, inherent heterogeneity, and specific lithological and tectonic boundaries. The survey was carried out in November 2020 using PQWT S500 equipment to a depth of $150 \mathrm{~m}$ along the profile with a distance between the electrodes of $10 \mathrm{~m}$.

\section{Results and discussion}

The geophysical Profile 1 near the village of Novo Leski is located in the southeastern part of the Gotse Delchev valley (Fig. 2). The Proterozoic rocks of the Dobrostan marble formation are exposed on the surface. The Neogene filling of the basin consists of the sediments of the Nevrokop Formation. The fault zone between the marbles and the terrigenous Neogene sediments, which marks the boundary of the basin, is partially overlapped by proluvial sediments (Kozhoukharov, Marinova, 1991).

The geophysical survey shows significant heterogeneity of the geological environment, including the degree of permeability of the rocks (Fig. 3). The western end of the profile crosses the fault zone on the periphery of the Dobrostan marble formation, which is represented by broken and crushed marbles. This is a prerequisite for the accumulation of water in depth, as well as for the appearance of springs in the area. This zone covers the first 100 meters from the beginning of the profile and covers almost the entire studied thickness in depth.

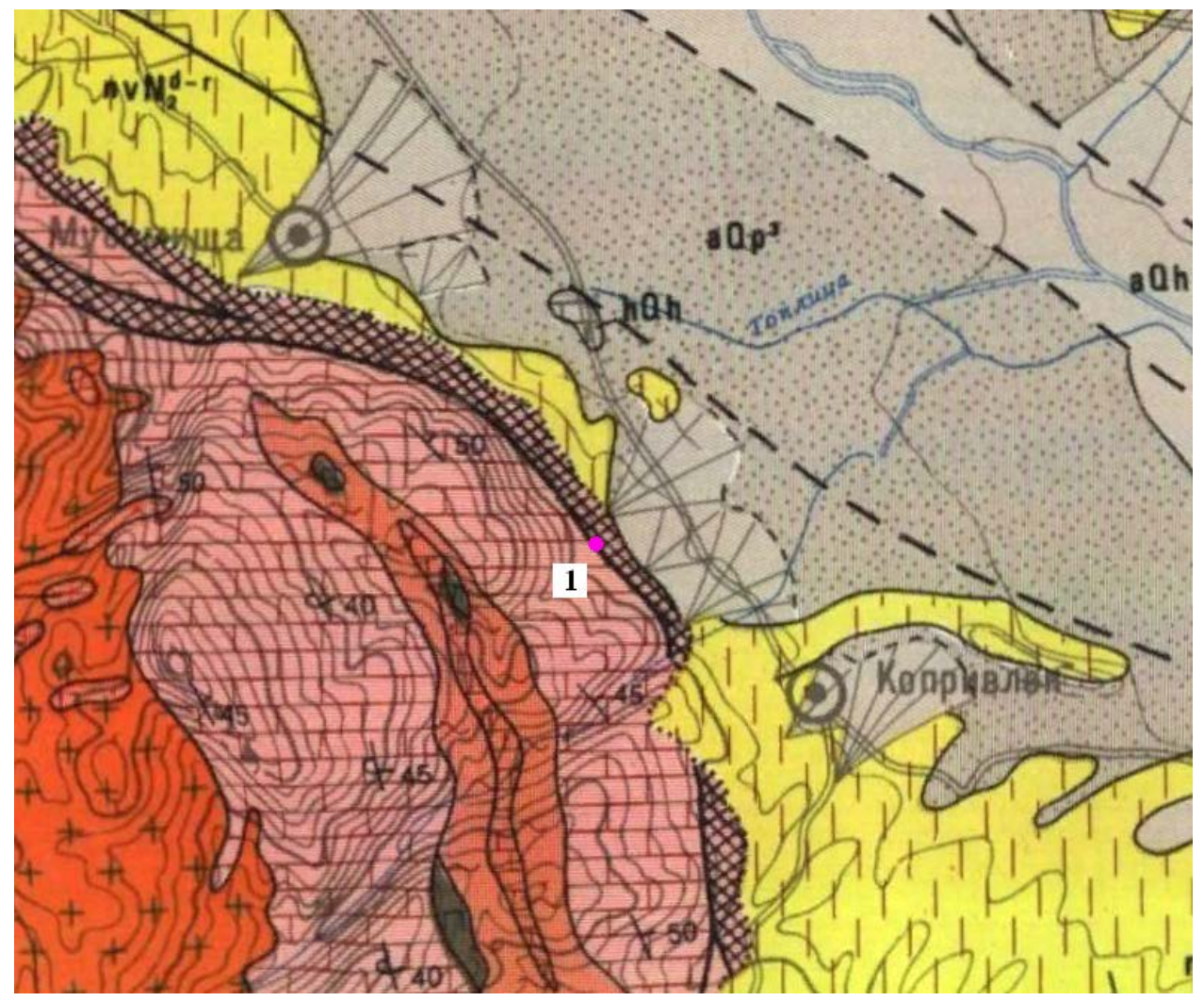

Fig. 2. Location of the Profile 1 on geological map in M 1: 100 000, map sheet Gotse Delchev (Kozhoukharov, Marinova, 1991)

Fig. 2. Location of the Profile 1 on geological map in M 1: 100 000, map sheet Gotse Delchev (Kozhoukharov, Marinova, 1991) 


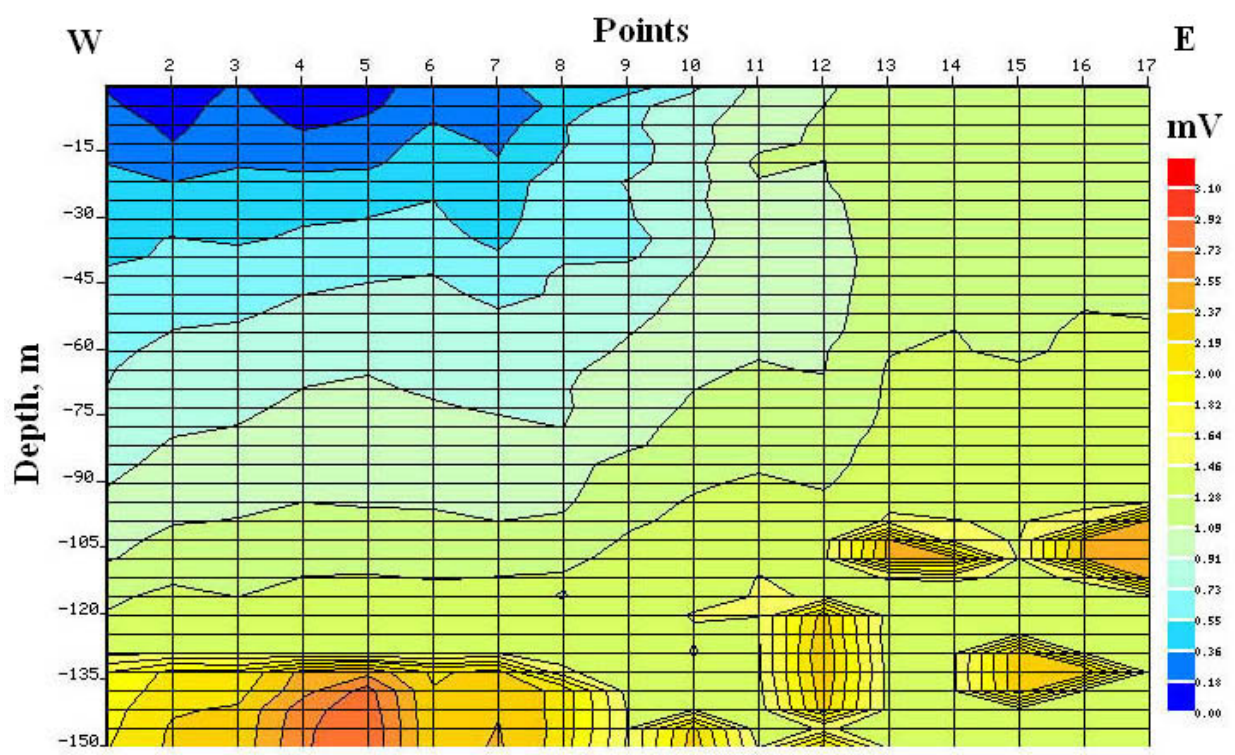

Fig. 3. Results of the geophysical survey for Profile 1 near the village of Novo Leski (U [mV])

Фиг. 3. Резултати от геофизичното проучване - Профил 1, с. Ново Лески

Low voltage values mark water-rich zones in depth, with the most active water exchange up to 130 meters. In the eastern direction, the measured voltage values decrease and delineate the boundary of the fault zone with proluvial materials, characterized by lithological and low water abundance of the contact. Higher values in depth indicate the PreCambrian basement bedrock, as well as individual larger blocks in the section.

The geophysical Profile 2 near the village of Ognyanovo (Fig. 4) is located in the northeastern part of the valley, on the periphery of the proluvial cone of Kanina River. It crosses a fault in the Neogene sediments (Baldevo Formation) at the contact with the outcropping proluvial sediments (Kozhoukharov, Marinova, 1991).

The most water productive zone is the upper part of the section is marked by low values of the measured voltage (Fig. 5). At a depth of $135 \mathrm{~m}$ hard rocks are found, which are apparently faulted at a distance of 20,90,120 m from the beginning of the profile. Probably, the PreCambrian basement bedrock lies at this depth below the Neogene deposits.

The geophysical Profile 3 near the village of Kremen is located in the high northern part of the Gotse Delchev valley at an altitude of $1140 \mathrm{~m}$. The geological map (Marinova, Katskov, 1990) outlines the contact of PreCambrian metamorphic rocks from the Rupchoska Group (Bogutevo plagio-gneiss Formation) and from the Rhodope supergroup (metagabbro and metadiorites) (Fig. 6).

Compared to Profiles 1 and 2, Profile 3 shows close values of the measured voltage (Fig. 7). Only the upper part of the section is relatively more water-rich. In depth, the values of electrical resistance gradually increase, as denser rocks with the highest values for the profile are registered in the range of 100-140 m.

The contact between the two types of metamorphic rocks is probably in the upper $10 \mathrm{~m}$ of the section, without being clearly marked. It is possible that it is better expressed deeper. 


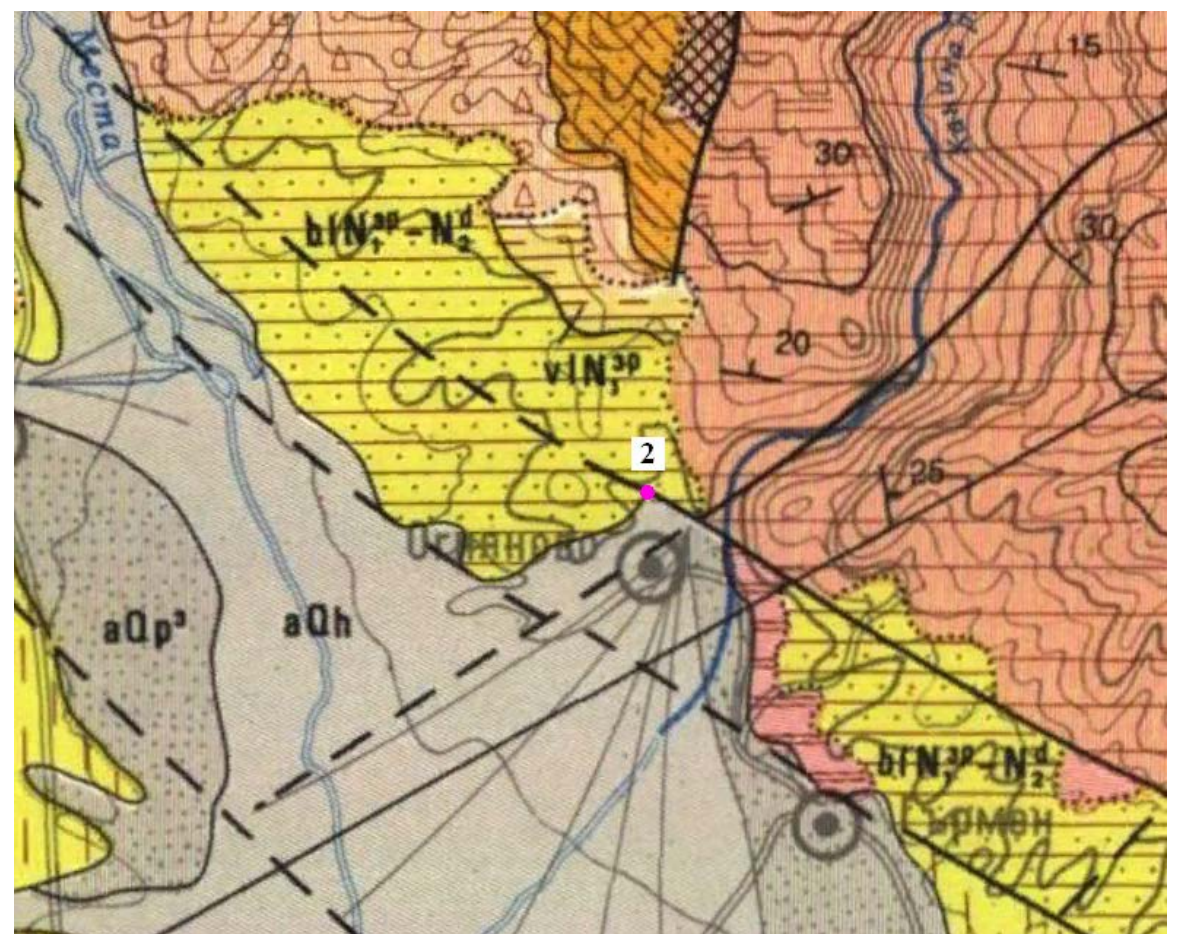

Fig. 4. Location of the Profile 2 on geological map in M 1: 100000 , map sheet Gotse Delchev (Kozhoukharov, Marinova, 1991)

Фиг. 4. Разположение на Профил 2 върху геоложка карта М 1:100000, к.л. Гоце Делчев (Kozhoukharov, Marinova, 1991)

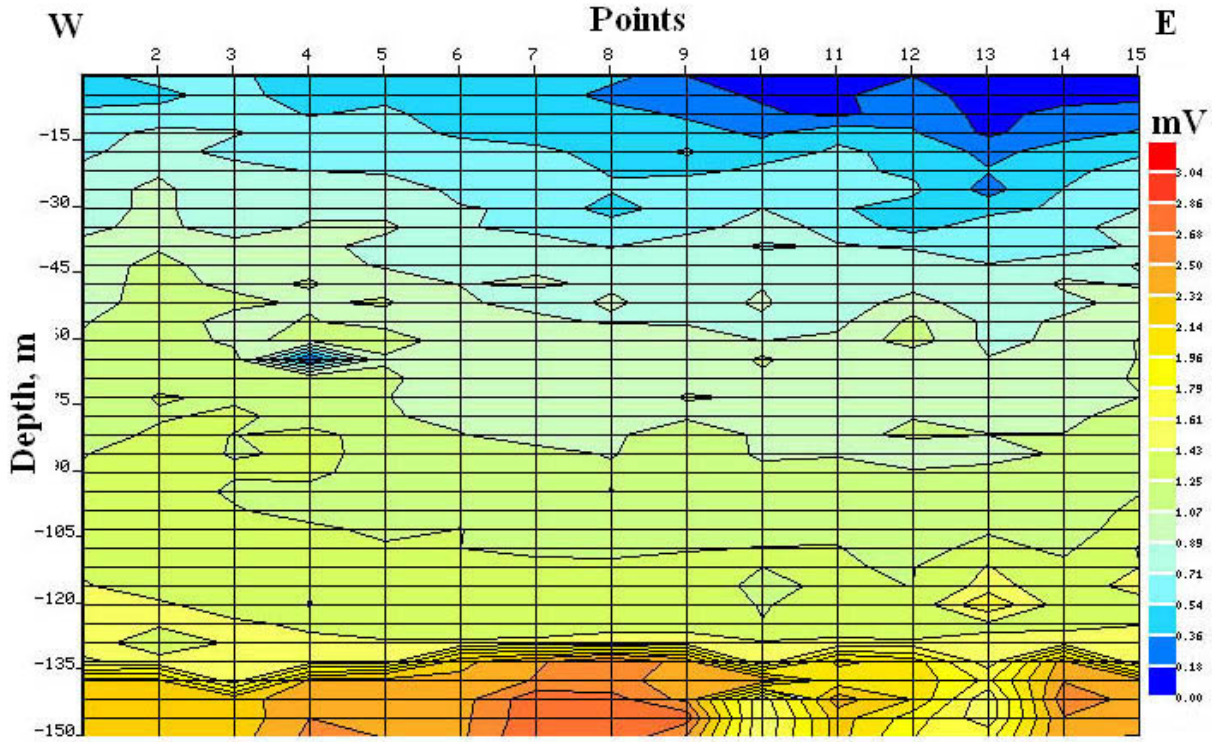

Fig. 5. Results of the geophysical survey for Profile 2 near the village of Ognyanovo (U $[\mathrm{mV}])$ Фиг. 5. Резултати от геофизичното проучване - Профил 2, с. Огняново 


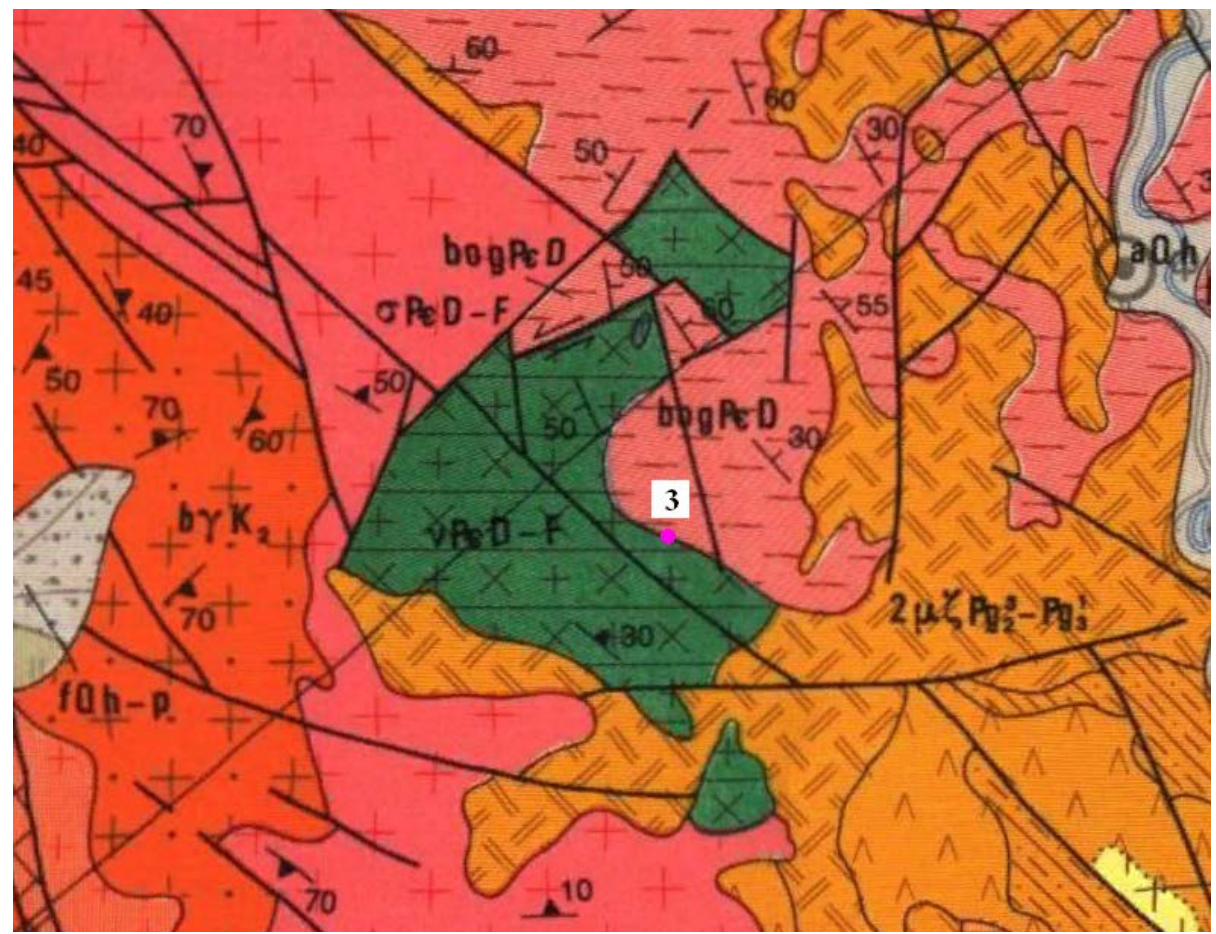

Fig. 6. Location of the Profile 3 on geological map in M 1: 100 000, map sheet Belitsa (Marinova, Katskov, 1990) Фиг. 6. Разположение на Профил 3 върху геоложка карта М 1:100000, к.л. Белица (Marinova, Katskov, 1990)

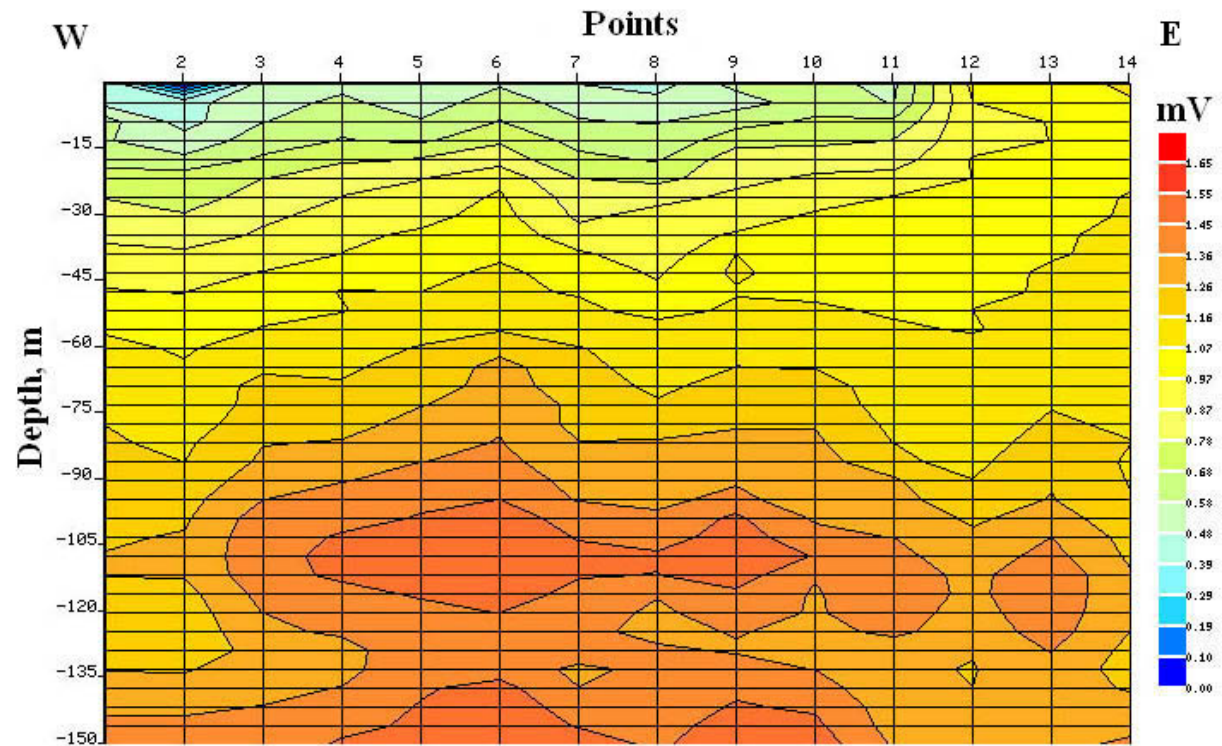

Fig. 7. Results of the geophysical survey for Profile 3 near the village of Kremen (U [mV]) Фиг. 7. Резултати от геофизичното проучване - Профил 3, с. Кремен 


\section{Conclusion}

The geological and lithological structure of the Gotse Delchev valley predetermines the general features of the hydraulic heterogeneity of the rocks, related to the general hydrogeological conditions. In order to obtain more precise data for specific sites, a geophysical survey was conducted using the SP (self-potential) method.

The results of the measurements allowed to locate water abundant zones that are related to proluvial deposits. Additionally, the image from the geophysical profiling reflects the geological structure in depth. The presence of faults has been confirmed and the depth of the basement rocks below the sedimentary cover has been determined. In general, the application of the SP method provided valuable additional information about the local features of the studied sites of the Gotse Delchev valley.

\section{Acknowledgements}

This work has been carried out in the framework of the National Science Program "Environmental Protection and Reduction of Risks of Adverse Events and Natural Disasters", approved by the Resolution of the Council of Ministers № 577/17.08.2018 and supported by the Ministry of Education and Science (MES) of Bulgaria (Agreement № Д01-363/17.12.2020).

\section{References}

Antonov, H., D. Danchev. 1980. Groundwater in the Republic of Bulgaria. Technika, Sofia, 360 p. (in Bulgarian).

Binley, A., S. S. Hubbard, J. A. Huisman, A. Revil, D. A. Robinson, K. Singha, L. D. Slater. 2015. The emergence of hydrogeohysics for improved understanding of subsurface processes over multiple scales. Water resources research, 51(6), 38373866. https://doi.org/10.1002/2015WR017016.

Gerginov, P., T. Orehova. 2020. Clarification of local hydrogeological conditions in the Razlog valley with the application of SP method. In: Book of Proceedings, Volume 2, Second Scientific Conference "Climate, atmosphere and water resources in the face of climate change, (eds: Chapanov, Y., T. Orehova, E. Bournaski), 242-248 (in Bulgarian with English abstract).

Kirsch, R. (ed.) 2006. Groundwater geophysics. Berlin: Springer, 493 p. https://doi. org/10.1007/3-540-29387-6.

Klimov, I., S. Sarov (eds.). 2009. Explanatory note to the Geological map of the Republic of Bulgaria, scale 1:50000, map sheet K-34-96-A (Gotse Delchev). Sofia, Ministry of Environment and Water, Bulgarian National Geological Survey, Printed by "Uniscorp" Ltd., 63 p. (in Bulgarian).

Kozhoukharov, D., R. Marinova. 1991. Geological map of Republic of Bulgaria in scale 1:100000, Gotse Delchev map sheet. Committee of Geology and Mineral Resources, Geology and Geophysics Ltd.

Kozhoukharov, D., R. Marinova. 1994. Explanatory note for the geological map of the Republic of Bulgaria in scale 1:100 000, Gotse Delchev map sheet. Committee of Geology and Mineral Resources, Geology and Geophysics Ltd, Sofia, 57 p. (in Bulgarian, with English abstract).

Marinova, R., N. Katskov, 1990. Geological map of Republic of Bulgaria in scale 1:100000, Belitsa map sheet. Committee of Geology and Mineral Resources, Geology and Geophysics Ltd.

Mitev, A., \& Yaneva, M. 2013. Application of 2D Resistivity Profiling for Delineation of Specific Lithological Bodies. Comptes rendus de l'Académie bulgare des Sciences, 66, 2, 231-234, https://doi.org/10.7546/CR-2013-66-2-13101331-10. 
Robert, T., A. Dassargues, S. Brouyère, O. Kaufmann, V. Hallet, F. Nguyen. 2011. Assessing the contribution of electrical resistivity tomography (ERT) and selfpotential (SP) methods for a water well drilling program in fractured/karstified limestones. Journal of Applied Geophysics, 75(1), 42-53, https://doi.org/10.1016/j. jappgeo.2011.06.008.

Sarov, S. (ed.). 2010. Explanatory note to the Geological map of the Republic of Bulgaria, scale 1:50000, map sheet K-34-84-V (Dobrinishte). Sofia, Ministry of Environment and Water, Bulgarian National Geological Survey, Printed by "Uniscorp" Ltd., 60 p.

Vasileva, T. 2020. Evaluation of Heavy Metal Pollution Index (HPI) and Metal Index (MI) of the groundwater in the Mesta River Basin, SW Bulgaria. Review of the Bulgarian Geological Society, 81, 2, 3-12 (in Bulgarian with English abstract), https://doi.org/10.52215/rev.bgs.2020.81.2.1.

Vasileva, T., A. Toteva. 2019. Hydrochemical characterization of shallow groundwater from the Mesta River Basin. Engineering Geology and Hydrogeology, 33, 15-26 (in Bulgarian with English abstract)

Vasileva, T., D. Sholev. 2021. Groundwater chemistry: a case study of the Mesta River Basin. Geologica Balcanica, 50, 2, 35-46, https://doi.org/10.52321/ GeolBalc.50.2.35.

Постъпила: 16.11 .2021

Received: 16 November 2021

Приета: 20.12.2021

Accepted: 20 December 2021 
62 Geological Institute, Bulgarian Academy of Sciences (C) 